\title{
Review \\ Aqueous contaminant removal by metallic iron: Is the paradigm shifting?
}

\author{
C Noubactep* \\ Angewandte Geologie, Universität Göttingen, Goldschmidtstraße 3, D - 37077 Göttingen, Germany; \\ Kultur und Nachhaltige Entwicklung CDD e.V., Postfach 1502, D - 37005 Göttingen, Germany
}

\begin{abstract}
Chemical reduction has long dominated thinking about the mechanism of aqueous contaminant removal in the presence of metallic iron (e.g. $\mathrm{Fe}^{0} / \mathrm{H}_{2} \mathrm{O}$ systems). However, a large body of experimental evidence indicates that chemical reduction is not adequate to satisfactorily explain the efficiency of $\mathrm{Fe}^{0} / \mathrm{H}_{2} \mathrm{O}$ systems for several substances or classes of substances. By contrast, the alternative approach, that contaminants are fundamentally adsorbed and co-precipitated by iron corrosion products seems to provide a better explanation of observed efficiency. The new approach appears to not be fully understood. The present communication aims at clarifying this key issue. It seems that a paradigm shift is necessary for the further development of the technology using $\mathrm{Fe}^{0}$ for water treatment.
\end{abstract}

Keywords: contaminant removal, paradigm shift, removal mechanism, water treatment, zero-valent iron

\section{Introduction}

The publication by Thomas Kuhn (1962) of his book The Structure of Scientific Revolutions was the starting point for the frequent use of the word 'paradigm' in many fields of science. Kuhn characterised a paradigm as a shared theory of the nature of something or of how it operates, together with a related set of problems to be solved and a kit of tools or methods for approaching those problems (Heaney, 2003; Rowbottom, 2011). Researchers introduced into a field, learned about the paradigm. Their challenge is to apply some tools of the prevailing paradigm to clarify some of its unsolved problems. For the field of water treatment with metallic iron $\left(\mathrm{Fe}^{0}\right)$, it is safe to say that contaminant reduction by $\mathrm{Fe}^{0}$ constitutes the basis of its operative paradigm.

Since the introduction of $\mathrm{Fe}^{0}$ for water treatment in 1990 (Reynolds et al., 1990; Gillham and O'Hannesin, 1994), contaminants have been reported to be removed by reductive transformations (Matheson and Tratnyek, 1994; Weber, 1996; O'Hannesin and Gillham, 1998; Comba et al., 2011). Clearly, contaminants were considered to be removed because of their chemical transformations possibly making them less harmful (degradation) or less mobile (precipitation). Accordingly, the case for which contaminant reduction products may be more toxic than parent contaminants (e.g. $\mathrm{CCl}_{4}$ ) is still actively discussed (Jiao et al., 2009; Alvarado et al., 2010). Moreover, the formation of the universal oxide film on the $\mathrm{Fe}^{0}$ surface (reactivity loss) and the pore filling by iron corrosion products (permeability loss) have been regarded as the major inhibitive factors for the process of contaminant removal (Henderson and Demond, 2007; Ghauch, 2008a; Simon et al., 2008; Li and Benson, 2010). Accordingly, 3 major problems of the $\mathrm{Fe}^{0}$

\footnotetext{
* To whom all correspondence should be addressed.

Im +49 55139 3191; fax: +49 551 399379; e-mail: cnoubac@gwdg.de

Received 27 September 2010; accepted in revised form 30 May 2011.
}

technology thus introduced are:

- How can harmful reaction products be removed?

- How can reactivity loss be prevented?

- How can permeability loss be properly considered?

Several analytical tools and complicated experimental devices has been used over the past 2 decades to search for answers to these 3 questions (Wilderer et al., 2002; McGuire et al., 2003; Simon et al., 2004). Even today, a cursory survey of the literature on $\mathrm{Fe}^{0}$ technology will find, in the introduction to virtually every paper, phrases such as ${ }^{\prime} . . . \mathrm{Fe}^{0}$ is proved to be particularly suitable for the decontamination of halogenated organic compounds, but subsequent studies have confirmed the possibility of using $\mathrm{Fe}^{0}$ for the reduction of nitrate, bromated, chlorate, nitro aromatic compounds, brominated pesticides. $\mathrm{Fe}^{0}$ proved to be effective in removing arsenic, lead, uranium and hexavalent chromium..." (Groza et al., 2009). It is important to notice that 'contaminant reduction' and 'contaminant removal' are mostly randomly interchanged.

It should be explicitly stated that some researchers have insisted on the importance of adsorption and/or co-precipitation in the process of aqueous contaminant removal by $\mathrm{Fe}^{0}$ (Burris et al., 1995; Allen-King et al., 1997; Lackovic et al., 2000; Lavine et al., 2001; Furukawa et al., 2002; Ritter et al., 2002; Wilkin and McNeil, 2003; Su and Puls, 2004; Mielczarski et al., 2005). However, their arguments were limited to inorganic contaminants (e.g. Lackovic et al., 2000; Wilkin and McNeil, 2003), to selected organic species (e.g. Mielczarski et al., 2005), or to investigations on the impact of iron corrosion products as contaminant scavengers (Furukawa et al., 2002; Jia et al. 2007) or reducing agents (Refait et al., 1998; Ritter et al., 2002; O'Loughlin et al., 2003; O'Loughlin and Burris, 2004; Chaves, 2005 ; Liang and Butler, 2011). For example, Furukawa et al. (2002) stated that under oxic conditions, ferrihydrite may be one of the most abundant iron corrosion products and may play an important role in adsorbing contaminants. In such situations, the use of $\mathrm{Fe}^{0}$ reactive walls 'may be extended to applications that require contaminant adsorption rather than, or in 


\begin{tabular}{|c|c|c|c|c|}
\hline \multicolumn{5}{|c|}{$\begin{array}{l}\text { Table } 1 \\
\text { Overview of important results of the first } 4 \text { published peer-reviewed articles on the } \mathrm{Fe}^{\mathrm{o}} / \mathrm{H}_{2} \mathrm{O} \\
\text { system (1994) and the number of citations of these as reported by Scopus }(27 \mathrm{March} \mathrm{2011).} \\
\text { It can be seen that none of these seminal works has demonstrated quantitative contaminant } \\
\text { reduction. Moreover, the least cited work is the one which has created conditions for } \\
\left.\text { favourable contaminant reduction (acidification by FeS }{ }_{2}\right) \text {. } \\
X \text { stands for contaminant; } \mathrm{RCl} \text { is a chlorinated hydrocarbon. }\end{array}$} \\
\hline Reference & Systems & $\mathbf{x}$ & Findings & Citations \\
\hline Matheson and Tratnyek & $\mathrm{Fe}^{0} / \mathrm{H}_{2} \mathrm{O}$ & $\mathrm{CH}_{\mathrm{x}} \mathrm{Cl}_{\mathrm{y}}$ & Degradation mostly by $\mathrm{Fe}^{0}$ & 616 \\
\hline Gillham and O'Hannesin & $\mathrm{Fe}^{0} / \mathrm{H}_{2} \mathrm{O}$ & $\frac{x}{\mathrm{RCl}}$ & Enhanced degradation & 597 \\
\hline Schreier and Reinhard & $\mathrm{Fe}^{0} / \mathrm{H}_{2} \mathrm{O}$ & $\mathrm{C}_{2} \mathrm{Cl}_{4}$ & Partial degradation & 65 \\
\hline Lipczynska-Kochany et al. & $\mathrm{Fe}^{0} / \mathrm{FeS}_{2} / \mathrm{H}_{2} \mathrm{O}$ & $\mathrm{CCl}_{4}$ & $\mathrm{FeS}$, accelerates degradation & 49 \\
\hline
\end{tabular}

addition to, redox-promoted contaminant degradation'. On the other hand, the findings of Lackovic et al. (2000) that arsenic is not removed by a reductive transformation process were clearly presented as an exception. It is important to note that results from the very first peer-reviewed articles on the $\mathrm{Fe}^{0} / \mathrm{H}_{2} \mathrm{O}$ systems were uncertain about the real mechanisms of contaminant removal (Table 1). However, the hypothesis of contaminant reduction was favoured without experimental evidence (e.g. mass balance) (e.g. Lee et al., 2004). As stated by O'Hannesin and Gillham (1998), it was a 'broad consensus'.

The kit of tools to investigate contaminant reduction includes a large number of highly sophisticated instruments for determining contaminant concentration and speciation, identifying contaminant reaction products and iron corrosion products as well (McGuire et al., 2003). Tools further used aimed at properly modelling experimental data and thus design field $\mathrm{Fe}^{0}$ treatment units (e.g. field reactive walls, household filters) (Schüth et al., 2003; VanStone et al., 2005; Li et al., 2006; Kouznetsova et al., 2007; Klammler and Hatfield, 2008; Li and Benson, 2010; Jeen et al., 2011). Additionally, researchers were organised in networks (e.g. PRBT - the US Permeable Reactive Barriers Action Team; RUBIN - the German Permeable Reactive Barrier Network; PRB-Net - the Permeable Reactive Barrier Network in the United Kingdom) having the goal to accelerate the development of the promising $\mathrm{Fe}^{0}$ technology. Thus, it would seem that the role of reductive transformation in the process of contaminant removal by $\mathrm{Fe}^{0}$ fulfils all of the criteria for a true paradigm.

It should be acknowledged that the reductive transformation concept has been a fruitful paradigm, fuelling substantial progress for the achieved acceptance of the $\mathrm{Fe}^{0}$ technology (Bigg and Judd, 2000; Scherer et al., 2000; Henderson and Demond, 2007; Laine and Cheng, 2007; Cundy et al., 2008; Thiruvenkatachari et al., 2008; Groza et al., 2009; Muegge and Hadley, 2009; Gillham, 2010; Phillips et al., 2010).

Nevertheless, a growing body of evidence indicates that factors other than reductive transformations contribute importantly to the process of contaminant removal in $\mathrm{Fe}^{0} / \mathrm{H}_{2} \mathrm{O}$ systems. These factors included adsorption, co-precipitation and adsorptive size exclusion.

\section{Limits of the reductive transformation concept}

Concordant reports on enhanced $\mathrm{Fe}^{0}$ reactivity towards aqueous contaminant removal with decreasing particle size have been reported. As a consequence, nano-scale $\mathrm{Fe}^{0}$ (nano- $\mathrm{Fe}^{0}$ ) has been suggested and is currently injected into the subsurface for groundwater remediation (Wang and Zhang, 1997; Comba et al., 2011; Shi et al., 2011). Another common tool to enhance $\mathrm{Fe}^{0}$ reactivity is the use of bimetallic materials $(\mathrm{Fe} / \mathrm{Cu}, \mathrm{Fe} /$ $\mathrm{Ni}, \mathrm{Fe} / \mathrm{Pd}$ ) (Muftikian et al., 1995). However, neither the use of nano- $\mathrm{Fe}^{0}$ (Noubactep and Caré, 2010a) nor that of bimetallic systems (Noubactep, 2009a) is consistent with the fact that contaminants should be reduced by $\mathrm{Fe}^{0}$. While the plating metals (e.g. $\left.\mathrm{Cu}^{0}, \mathrm{Ni}^{0}, \mathrm{Pd}^{0}\right)$ are concurrent reagents for $\mathrm{Fe}^{0}$ oxidation, nano- $\mathrm{Fe}^{0}$ will be readily oxidised by water which is in stoichiometric excess relative to dissolved contaminants. Both of these facts ('anomalies') are the first arguments against the view that contaminants are quantitatively removed by reductive transformations.

Several other experimental results seem to have stretched the reductive transformation paradigm to the point where it may no longer be intellectually satisfying. Among these results (Noubactep, 2007; Noubactep, 2010a; Scott et al., 2011 and references cited therein) are:

- The quantitative removal of species like $\mathrm{Zn}^{\mathrm{II}}$ which is not reducible by $\mathrm{Fe}^{0}$ or the quantitative removal of $\mathrm{Mo}^{\mathrm{VI}}$ which is not readily adsorbed on iron oxides (at $\mathrm{pH}>6$ )

- The quantitative removal of organic species in $\mathrm{Fe}^{0}$ beds which were proven as non-reducible by $\mathrm{Fe}^{0}$ in batch systems (Lai et al., 2006)

- The existence of the lag time in the process of contaminant removal in batch systems (Schreier and Reinhard, 1994; Hao et al., 2005).

Where the reductive transformation paradigm is not useful, researchers have favoured selective adsorption or microbial processes to explain observed results (Lai et al., 2006). However, this approach can be regarded as a falsification of the reductive transformation paradigm since it assumes that adsorption is only important when reduction is not favourable. Moreover, contaminant co-precipitation with precipitating and transforming iron oxides is considered only for specific cases, as discussed above. This is the juncture (proliferation of anomalies) at which Kuhn observes that paradigms tend to shift (Heaney, 2003).

The expression 'paradigm shift' is believed to be misused or overused in science. For this reason, this communication proposes that the reductive transformation paradigm is giving way to a successor that seems to provide an operationally superior and intellectually more attractive rationalisation of the process of aqueous contaminant removal by $\mathrm{Fe}^{0}$.

It must be acknowledged that the principle that contaminants are quantitatively removed in $\mathrm{Fe}^{0} / \mathrm{H}_{2} \mathrm{O}$ systems has never been in question. The sole discussion is about the occurrence of reduction (if applicable) and its extent (Lee et al., 2004). The next section will briefly present a different view on the process of contaminant removal which is the essence of the alternative paradigm. The new concept suggests an analogy with the historical work of Yao et al. (1971) that contaminants are collected in $\mathrm{Fe}^{0}$ beds (deep bed filters) by in situ generated $\mathrm{Fe}^{\mathrm{II}} / \mathrm{Fe}^{\mathrm{II}}$-species, regardless of whether they are chemically transformed or not. 


\section{Adsorption/co-precipitation concept}

The concept that contaminants are fundamentally adsorbed and/or co-precipitated onto/with iron corrosion products in $\mathrm{Fe}^{0}$ \% $\mathrm{H}_{2} \mathrm{O}$ systems has been extensively presented in several recent articles (e.g. Noubactep, 2010a; 2010b). The concept arose from a fortuitous observation during experiments on the process of uranium removal in ' $\mathrm{Fe}^{0} / \mathrm{MnO}_{2} / \mathrm{H}_{2} \mathrm{O}$ ' systems (' $\mathrm{Fe}^{0}$, ' $\mathrm{MnO}_{2}$ ' and ' $\mathrm{Fe}^{0}+\mathrm{MnO}_{2}$ ') (Noubactep et al., 2003) and is supported by results from all other branches of science involving aqueous iron corrosion (Noubactep, 2009b; Noubactep and Schöner, 2009; Noubactep and Schöner, 2010).

In the mentioned experiments, $\mathrm{MnO}_{2}$ and waterworks sludge (aged iron oxides $-\mathrm{Fe}_{2} \mathrm{O}_{3}$ ) were used as relevant adsorbents and their impact on the process of $\mathrm{U}^{\mathrm{VI}}$ removal by $\mathrm{Fe}^{0}$ was characterised. Results showed that none of the adsorbents could significantly accelerate $\mathrm{U}^{\mathrm{VI}}$ removal. Moreover, $\mathrm{MnO}_{2}$ essentially retarded $\mathrm{U}^{\mathrm{VI}}$ removal and the lag time was proportional to the available amount of $\mathrm{MnO}_{2}$. These results indicated that $\mathrm{U}^{\mathrm{VI}}$ is mostly removed by in-situ generated iron corrosion products. Aged $\mathrm{Fe}_{2} \mathrm{O}_{3}$ could not significantly impact $\mathrm{U}^{\mathrm{VI}}$ removal. $\mathrm{MnO}_{2}$ essentially retarded the removal process. This delay is due to the fact that iron hydroxides are not precipitated in the vicinity of $\mathrm{Fe}^{0}$ but rather at the surface of $\mathrm{MnO}_{2}$. The process of reductive dissolution of $\mathrm{MnO}_{2}$ by $\mathrm{Fe}^{\mathrm{II}}$ is a well-documented geochemical process (Stone, 1987; Stone and Ulrich, 1989; Postma and Appelo, 2000; Kang et al., 2006).

A close consideration of the impact of $\mathrm{MnO}_{2}$ on the process of $\mathrm{U}^{\mathrm{VI}}$ removal by $\mathrm{Fe}^{0}$ suggested that $\mathrm{U}^{\mathrm{VI}}$ removal is a characteristic of corroding iron. In other words, $\mathrm{U}^{\mathrm{VI}}$ removal is not necessarily a reductive process or a result of any specific interactions between $\mathrm{U}^{\mathrm{VI}}$ and $\mathrm{Fe}^{0}$. Specific interactions between contaminants and $\mathrm{Fe}^{0}$ (and iron oxides) will certainly favour the removal process but are not the determinant factors (Scott et al., 2011). Accordingly, a $\mathrm{Fe}^{0} / \mathrm{H}_{2} \mathrm{O}$ system can be regarded as a domain of precipitating iron hydroxide (Noubactep, 2009c). In such a system, any inflowing contaminant will be adsorbed and co-precipitated. Additionally, $\mathrm{Fe}^{\mathrm{II}}$ and $\mathrm{H} / \mathrm{H}_{2}$ from continuously corroding $\mathrm{Fe}^{0}$ are reducing agents for reducible contaminants in the system but the extent of contaminant reduction is difficult to discuss because generated iron oxides must be digested for contaminant speciation and mass balance calculations. On the other hand, contaminants enmeshed in the matrix of iron corrosion are stable for a long time under environmental conditions, whether they are chemically transformed or not (Noubactep et al., 2006).

The presentation above has explained why all classes of aqueous contaminants may be quantitatively removed by $\mathrm{Fe}^{0}$. It is clear from this presentation that parent contaminants and their reaction products are all removed in $\mathrm{Fe}^{0} / \mathrm{H}_{2} \mathrm{O}$ systems. This is consistent with the view that in a $\mathrm{Fe}^{0}$ bed in situ generated Fe hydroxides and oxides act as contaminant 'collectors' (Yao et al., 1971). Accordingly, one of the 3 major problems introduced (how can harmful reaction products be removed?) by the reductive transformation concept is solved. The remaining 2 problems are:

- How can reactivity loss be prevented?

- How can permeability loss be properly considered?

Answering these questions is beyond the scope of this communication. However, it should be pointed out that recent theoretical works have shown that to sustain system permeability, $\mathrm{Fe}^{0}$ should be admixed to inert materials in a volumetric ratio of less than $52 \%$. In other words, an efficient $\mathrm{Fe}^{0}$ bed could be regarded as a $\mathrm{Fe}^{0}$ amended sand filter. A proposed tool to sustain reactivity is to use $\mathrm{Fe}^{0} / \mathrm{MnO}_{2}$ mixtures (Noubactep et al., 2010).

The concept presented in this section clearly underplays the importance of reduction in the process of aqueous contaminant removal in $\mathrm{Fe}^{0} / \mathrm{H}_{2} \mathrm{O}$ systems. There is increasing evidence that this concept is not yet understood by authors who have referenced related papers. The next section will address this issue.

\section{Argumentation against the new concept}

The concept regarding adsorption and co-precipitation as the fundamental mechanisms of contaminant removal in $\mathrm{Fe}^{0} / \mathrm{H}_{2} \mathrm{O}$ systems has been experimentally validated using methylene blue as model contaminant (Noubactep, 2009d). The concept has recently been verified using clofibric acid (Ghauch et al., 2010a) and diclofenac (Ghauch et al., 2010b). Moreover, the similitude between contaminant removal with elemental metals and electro-coagulation has been excellently presented by Bojic et al. (2004; 2007; 2009). Nevertheless, there are currently 5 types of arguments in the literature downplaying the significance of this concept:

- The concept is wrongly referenced (Luna-Velasco et al., 2010; Yuan et al., 2010) (Argument 1)

- The concept is hardly acceptable because the reductive transformation concept is widely accepted in the scientific community, and self-citation is always used to support the validity of the new concept (Kang and Choi, 2009) (Argument 2)

- Good results on removal of inorganic species by $\mathrm{Fe}^{0}$ are unacceptably generalised (Ebert et al., 2007; Tratnyek and Salter, 2010) (Argument 3)

- Data are needed to support the repeated claims which negate more than 1 decade of intensive research (Ebert et al., 2007; Tratnyek and Salter, 2010) (Argument 4)

- Some authors who have correctly referenced the adsorption/co-precipitation concept deliberately ignored it in their subsequent publications (Argument 5).

For example, Flury and his colleagues (Flury et al., 2009a; 2009b) referenced Noubactep (2006) in a paper published in Applied Geochemistry (available online 24 December 2008) and not in the paper for Environmental Science \& Technology (accepted May 14, 2009). At the same time, three more recent papers which further elaborated on the new concept were available. In another example, Lo and co-workers correctly referenced the concept in 2008 (Rao et al., 2009; accepted 11 December 2008) but not in several subsequent works (e.g. Liu et al., 2009; Mak et al., 2009; 2011). Short comments on individual arguments are given below.

- Argument 1: The concept was introduced in 2007 in an open access journal (Noubactep, 2007). Therefore, there seems to be no reason why so many researchers would appear to have ignored or wrongly referenced it. Referencing articles using or presenting the new concept, co-precipitation is enumerated as a 'simple' reaction mechanism beside adsorption and reduction (Luna-Velasco et al., 2010; Yuan et al., 2010). That researchers appear to be ignoring state-of-the-art knowledge on the mechanism of contaminant removal in $\mathrm{Fe}^{0} / \mathrm{H}_{2} \mathrm{O}$ systems should be a concern for the whole community.

- Argument 2: The consistency of the concept of reductive transformation has been extensively discussed while 
introducing the concept of adsorption/co-precipitation. Researchers should have discussed the validity of the new concept instead of simply expressing doubt as to its validity. Fortunately, Ghauch, who was initially sceptical about the adsorption/co-precipitation concept (Ghauch, 2008b), has experimentally verified its efficiency in explaining processes which are still mistakenly attributed to plated $\mathrm{Fe}^{0}$ (Ghauch et al., 2010b).

- Argument 3: Not all inorganic substances are readily adsorbed onto iron oxides (iron corrosion products) (Blowes et al., 2000). For example, $\mathrm{Mo}^{\mathrm{VI}}$ is very poorly adsorbed on iron oxides at $\mathrm{pH}>6.0$ (Scott et al., 2011 and references cited therein) but was reported to be successfully removed by $\mathrm{Fe}^{0}$ (Morrison et al., 2002; 2006). On the other hand, many organic compounds are readily adsorbed onto iron oxides (Tipping and Higgins, 1982; Tipping, 1986; Gu et al., 1994, Satoh et al., 2006; Hanna and Boily, 2010; Eusterhues et al., 2011). Besides this evidence from the geochemical literature, it has been clearly demonstrated that contaminant removal is not primarily a property of contaminants but rather a characteristic of aqueous iron corrosion. In other words, contaminants are not removed by $\mathrm{Fe}^{0}$ or $\mathrm{Fe}$ oxides separately, but during the whole dynamic process of aqueous iron corrosion. In $\mathrm{Fe}^{0}$ beds, adsorptive size exclusion in deep bed filtration mode sustains the removal efficiency. The argument of self-citation is not acceptable because nobody else has systematically reported on the inconsistency of the reductive transformation concept. Moreover, authors like Burris et al. (1995), Lavine et al. (2001), Mantha et al. (2001) and Odziemkowski (2009), who have seriously questioned some aspects of the reductive transformation concept, have been continuously referenced.

- Argument 4 is mostly used by reviewers and referees who have rejected several manuscripts and proposals. Rejected manuscripts were subsequently accepted by other reviewers, sometimes from the same journal in a new submission. It is important in this regard to note that many reviewers have argued that the review articles presenting the concept of adsorption/co-precipitation could never have been published in ISI-referenced journals (Noubactep, 2006; 2007) or in journals with higher impact factors (Noubactep, 2008) because of the concept's poor scientific quality. While manuscripts could be revised and re-submitted, proposals have been systematically rejected. This is a well-known situation whenever a new view is introduced (Alm, 1992; Heaney, 2003).

- Argument 5 suggests that the ground-breaking nature of the concept was not clear to the authors who may have been prompted by peer-reviewers to reference related works.

The comments above showed that no single valid argument against the adsorption/co-precipitation concept has yet been presented. Moreover, theoretical studies related to this concept are a powerful guide for appropriate experimental designs (Noubactep and Caré, 2010a; 2010b; 2010c; Noubactep et al., 2009; Noubactep et al., 2010; Noubactep, 2011; Noubactep and Caré, 2011). On the other hand, regarding $\mathrm{Fe}^{0}$ beds as ' $\mathrm{Fe}^{0}$ amended sand filters' suggests that population balance models that account for pore and particle size distributions along with pore space topology (e.g. Bedrikovetsky, 2008) describe processes in dynamic $\mathrm{Fe}^{0} / \mathrm{H}_{2} \mathrm{O}$ systems with better accuracy than currently-used models (Jeen et al. 2011).

\section{Concluding remarks}

The use of $\mathrm{Fe}^{0}$ for water treatment was based on the thermodynamically valid argument that $\mathrm{Fe}^{0}$ is a relative strong reducing agent $\left(\mathrm{E}^{0}=-0.44 \mathrm{~V} / \mathrm{ESH}\right)$. However, this assumption has overseen at least 2 important aspects of aqueous iron corrosion and their thermodynamics: solubility of iron hydroxides; and adhesion of oxide scale on metal (Noubactep, 2010a; 2010b). In fact, whether contaminant reduction by $\mathrm{Fe}^{0}$ (direct reduction) occurs and contributes significantly to the process of contaminant removal remains unclear. However, it is certain that several groups of contaminants are quantitatively removed in $\mathrm{Fe}^{0} / \mathrm{H}_{2} \mathrm{O}$ systems and that these contaminants are adsorbed and co-precipitated (Noubactep, 2009d; Ghauch et al., 2010a; 2010b). Adsorbed and co-precipitated contaminants could be further reduced by electrons from $\mathrm{Fe}^{0}$ (direct reduction), but more likely by electrons from $\mathrm{Fe}^{\mathrm{II}}$ or $\mathrm{H} / \mathrm{H}_{2}$ (indirect reduction). Additionally, some contaminants could be oxidised in the systems by in-situ generated Fenton-like reagents (Ghauch et al., 2010b). It is the aim of this communication to propose the substitution of the reductive transformation concept by that of adsorption/co-precipitation (and adsorptive size-exclusion).

It has been argued that 'no paradigm passes painlessly' (Heaney, 2003). The scientific objectivity should dictate the fate of any scientific concept regardless of its age or what has been invested in it. In the author's opinion, the proposed paradigm shift does not represent a danger for any industry but rather a chance for more systematic system designs. For example, the elimination of the constraint that contaminants should be reduced implies that surrogate parameters (e.g. dissolved organic carbon - DOC) can be used to monitor effluents for organics from treatment systems until breakthrough occurs. Afterwards, more precise analytic tools are needed to identify escaped organic species. On the other hand, the proposed new paradigm has enabled a better bed design and clarified the controversial issue of using inert admixture in $\mathrm{Fe}^{0}$ beds (Noubactep et al., 2010). Furthermore, the new paradigm is about to revive $\mathrm{Fe}^{0}$ household filters, e.g. the 3-Kolshi filters (Khan et al., 2000; Hussam and Munir, 2007; Hussam, 2009). The 3-Kolshi filters have been abandoned because of poor design, as recently demonstrated (Noubactep et al., 2010). The 3-Kolshi filters were replaced by very sustainable filters (SONO filters) in which iron shavings/filings were substituted by a porous $\mathrm{Fe}^{0}$-based composite (Hussam and Munir, 2007; Hussam, 2009).

The adsorption/co-precipitation concept has demonstrated that reduction is less important for the process of contaminant removal than had previously been assumed (O'Hannesin and Gillham, 1998; Gillham, 2010). Because contaminants are progressively enmeshed in the matrix of iron corrosion products, they are even more stable than if they were simply reduced or degraded. Accordingly, the proposed paradigm even sustains the acceptance of the $\mathrm{Fe}^{0}$ technology. Researchers are given more possibilities for rational and systematic investigations of contaminant removal in $\mathrm{Fe}^{0} / \mathrm{H}_{2} \mathrm{O}$ systems as they can pay less relative attention to contaminant speciation. It is hoped that this opportunity will be used for a rapid development of the $\mathrm{Fe}^{0}$ technology and its extension to other applications, as recently suggested by Antia (2010).

In conclusion, enhanced collaboration between experimental and modelling scientists is needed in order to expedite resolution of the key gaps in the understanding of the operation of processes governing the functionality of $\mathrm{Fe}^{0}$ filtration systems. This closed collaboration is essential to frame new $\mathrm{Fe}^{0}$ bed models. 


\section{Acknowledgments}

The original manuscript was improved by the insightful comments of Angelika Schöner (FSU Jena - Germany). The manuscript was further improved by the insightful comments of anonymous reviewers.

\section{References}

ALLEN-KING RM, HALKET RM and BURRIS DR (1997) Reductive transformation and sorption of cis- and trans-1,2-dichloroethene in a metallic iron-water system. Environ. Toxicol. Chem. 16 424-429.

ALM A (1992) Pollution prevention and TQM: Examples of paradigm shifts. Environ. Sci. Technol. 26 452-542.

ALVARADO JS, ROSE C and LAFRENIERE L (2010) Degradation of carbon tetrachloride in the presence of zero-valent iron. J. Environ. Monit. 12 1524-1530.

ANTIA DDJ (2010) Sustainable zero-valent metal (ZVM) water treatment associated with diffusion, infiltration, abstraction and recirculation. Sustainability 2 2988-3073.

BEDRIKOVETSKY P (2008) Upscaling of stochastic micro model for suspension transport in porous media. Transp. Porous Med. 75 335-369.

BIGG T and JUDD SJ (2000) Zero-valent iron for water treatment. Environ. Technol. 21 661-670.

BLOWES DW, PTACEK CJ, BENNER SG, MCRAE CWT, BENNETT TA and PULS RW (2000) Treament of inorganic contaminants using permeable reactive barriers. J. Contam. Hydrol. 45 123-137.

BOJIC A, PURENOVIC M and BOJIC D (2004) Removal of chromium(VI) from water by micro-alloyed aluminium based composite in flow conditions. Water SA 30 353-359.

BOJIC A, PURENOVIC M, BOJIC D and NDJELKOVIC T (2007) Dehalogenation of trihalomethanes by a micro-alloyed aluminium composite under flow conditions. Water SA 33 297-304.

BOJIC A, BOJIC D and ANDJELKOVIC T (2009) Removal of $\mathrm{Cu}^{2+}$ and $\mathrm{Zn}^{2+}$ from model wastewaters by spontaneous reduction-coagulation process in flow conditions. J. Hazard. Mater. 168 813-819.

BURRIS DR, CAMPBELL TJ and MANORANJAN VS (1995) Sorption of trichloroethylene and tetrachloroethylene in a batch reactive metallic iron-water system. Environ. Sci. Technol. 29 2850-2855.

CHAVES LHG (2005) The role of green rust in the environment: a review. Rev. Bras. Eng. Agríc. Ambient. 9 284-288.

COMBA S, DI MOLFETTA A and SETHI R (2011) A comparison between field applications of nano-, micro-, and millimetric zerovalent iron for the remediation of contaminated aquifers. Water Air Soil Pollut. 215 595-607.

CUNDY AB, HOPKINSON L and WHITBY RLD (2008) Use of ironbased technologies in contaminated land and groundwater remediation: A review. Sci. Total Environ. 400 42-51.

EBERT M, BIRKE V, BURMEIER H, DAHMKE A, HEIN P, KÖBER R, SCHAD H, SCHÄFER D and STEIOF M (2007) Kommentar zu den Beiträgen „Das Ende eines Mythos“ sowie „Zur Funktion reaktiver Wände“ von Dr. Chicgoua Noubactep. Wasser, Luft und Boden 7-8 TT4-5.

EUSTERHUES K, RENNERT T, KNICKER H, KGEL-KNABNER I, TOTSCHE KU and SCHWERTMANN U (2011) Fractionation of organic matter due to reaction with ferrihydrite: coprecipitation versus adsorption. Environ. Sci. Technol. 45 527-533.

FLURY B, EGGENBERGER U and MÄDER (2009a) First results of operating and monitoring an innovative design of a permeable reactive barrier for the remediation of chromate contaminated groundwater. Appl. Geochem. 24 687-696.

FLURY B, FROMMER J, EGGENBERGER U, MÄDER U, NACHTEGAAL M and KRETZSCHMAR R (2009b) Assessment of long-term performance and chromate reduction mechanisms in a field scale permeable reactive barrier. Environ. Sci. Technol. 43 6786-6792.

FURUKAWA Y, KIM J-W, WATKINS J and WILKIN RT (2002) Formation of ferrihydrite and associated iron corrosion products in permeable reactive barriers of zero-valent iron. Environ. Sci. Technol. 36 5469-5475.

GHAUCH A (2008a) Rapid removal of flutriafol in water by zerovalent iron powder. Chemosphere 71 816-826.

GHAUCH A (2008b) Discussion of Chicgoua Noubactep on "Removal of thiobencarb in aqueous solution by zero valent iron" by Md. Nurul Amin et al. [Chemosphere 70 (3) (2008) 511-515]. Chemosphere 72 328-331.

GHAUCH A, ABOU ASSI H and TUQAN A (2010a) Investigating the mechanism of clofibric acid removal in $\mathrm{Fe}^{0} / \mathrm{H}_{2} \mathrm{O}$ systems. J. Hazard. Mater. 176 48-55.

GHAUCH A, ABOU ASSI H and BDEIR S (2010b) Aqueous removal of diclofenac by plated elemental iron: Bimetallic systems. J. Hazard. Mater. 182 64-74.

GILLHAM RW and O'HANNESIN SF (1994) Enhanced degradation of halogenated aliphatics by zero-valent iron. Ground Water 32 958-967.

GILLHAM RW (2010) Development of the granular iron permeable reactive barrier technology (good science or good fortune). In: Chen Y, Tang X and Zhan L (eds.) Advances in Environmental Geotechnics: Proceedings of the International Symposium on Geoenvironmental Engineering in Hangzhou, China, September 8-10, 2009. Springer, Berlin/London. 5-15.

GROZA N, RADULESCU R, PANTURU E, FILCENCO-OLTEANU A and PANTURU RI (2009) Zero-valent iron used for radioactive waste water treatment. Chem. Bull. "POLITEHNICA" Univ. 54 21-25.

GU B, SCHMITT J, CHEN Z, LIANG L and McCARTHY JF (1994) Adsorption and desorption of natural organic matter on iron oxide: mechanisms, and models. Environ. Sci. Technol. 28 38-46.

HANNA K and BOILY J-F (2010) Sorption of two naphthoic acids to goethite surface under flow through conditions. Environ. Sci. Technol. 44 8863-8869.

HAO Z, XU X and WANG D (2005) Reductive denitrification of nitrate by scrap iron filings. J. Zhejiang Univ. Sci. 6B 182-187.

HEANEY RP (2003) Is the paradigm shifting? Bone 33 457-465.

HENDERSON AD and DEMOND AH (2007) Long-term performance of zero-valent iron permeable reactive barriers: a critical review. Environ. Eng. Sci. 24 401-423.

HUSSAM A (2009) Contending with a Development Disaster: SONO Filters Remove Arsenic from Well Water in Bangladesh. Innovations 4 89-102.

HUSSAM A and MUNIR AKM (2007) A simple and effective arsenic filter based on composite iron matrix: Development and deployment studies for groundwater of Bangladesh. J. Environ. Sci. Health A42 1869-1878.

JEEN S-W, GILLHAM RW and PRZEPIORA A (2011) Predictions of long-term performance of granular iron permeable reactive barriers: Field-scale evaluation. J. Contam. Hydrol. 123 50-64.

JIA Y, AAGAARD P and BREEDVELD GD (2007) Sorption of triazoles to soil and iron minerals. Chemosphere 67 250-258.

JIAO Y, QIU C, HUANG L, WU K, MA H, CHEN S, MA L and WU L (2009) Reductive dechlorination of carbon tetrachloride by zerovalent iron and related iron corrosion. Appl. Catal. B: Environ. 91 434-440.

KANG K-H, LIM D-M and SHIN H (2006) Oxidative-coupling reaction of TNT reduction products by manganese oxide. Water Res. 40 903-910.

KANG S-H and CHOI W (2009): Response to comment on "oxidative degradation of organic compounds using zero-valent iron in the presence of natural organic matter serving as an electron shuttle". Environ. Sci. Technol. 43 3966-3967.

KHAN AH, RASUL SB, MUNIR AKM, HABIBUDDOWLA M ALAUDDIN M, NEWAZ SS and HUSSAM A (2000) Appraisal of a simple arsenic removal method for groundwater of Bangladesh. J. Environ. Sci. Health A35 1021-1041.

KLAMMLER H and HATFIELD K (2008) Analytical solutions for flow fields near continuous wall reactive barriers. J. Contam. Hydrol. 98 1-14.

KOUZNETSOVA I, BAYER P, EBERT M and FINKEL M (2007) Modelling the long-term performance of zero-valent iron using a spatio-temporal approach for iron aging. J. Contam. Hydrol. 90 58-80. 
KUHN T (1962) The Structure of Scientific Revolutions. University of Chicago Press, Chicago.

LACKOVIC JA, NIKOLAIDIS NP and DOBBS GM (2000) Inorganic arsenic removal by zero-valent iron. Environ. Eng. Sci. 17 29-39.

LAI KCK, LO IMC, BIRKELUND V and KJELDSEN P (2006) Field monitoring of a permeable reactive barrier for removal of chlorinated organics. J. Environ. Eng. 132 199-210.

LAINE DF and CHENG IF (2007) The destruction of organic pollutants under mild reaction conditions: A review. Microchem. J. 85 183-193.

LAVINE BK, AUSLANDER G and RITTER J (2001) Polarographic studies of zero valent iron as a reductant for remediation of nitroaromatics in the environment. Microchem. J. 70 69-83.

LEE G, RHO S and JAHNG D (2004) Design considerations for groundwater remediation using reduced metals. Korean J. Chem. Eng. 21 621-628.

LI L and BENSON C (2010) Evaluation of five strategies to limit the impact of fouling in permeable reactive barriers. J. Hazard. Mater. 181 170-180.

LI L, BENSON CH and LAWSON EM (2006) Modeling porosity reductions caused by mineral fouling in continuous-wall permeable reactive barriers. J. Contam. Hydrol. 83 89-121.

LIANG X and BUTLER EC (2011) Effects of natural organic matter model compounds on the transformation of carbon tetrachloride by chloride green rust. Water Res. 44 2125-2132.

LIPCZYNSKA-KOCHANY E, HARMS S, MILBURN R, SPRAH G and NADARAJAH N (1994) Degradation of carbon tetrachloride in the presence of iron and sulphur containing compounds. Chemosphere 29 1477-1489.

LIU T, RAO P, MAK MSH, WANG P and LO IMC (2009) Removal of co-present chromate and arsenate by zero-valent iron in groundwater with humic acid and bicarbonate. Water Res. 43 2540-2548.

LUNA-VELASCO A, SIERRA-ALVAREZ R, CASTRO B and FIELD JA (2010) Removal of nitrate and hexavalent uranium from groundwater by sequential treatment in bioreactors packed with elemental Sulfur and zero-valent iron. Biotechnol. Bioeng. 107 933-942.

MAK MSH, RAO P and LO IMC (2009) Effects of hardness and alkalinity on the removal of $\operatorname{arsenic}(\mathrm{V})$ from humic acid-deficient and humic acid-rich groundwater by zero-valent iron. Water Res. 43 4296-4304.

MAK MSH, RAO P and LO IMC (2011) Zero-valent iron and iron oxide-coated sand as a combination for removal of co-present chromate and arsenate from groundwater with humic acid. Environ. Pollut. 159 377-382.

MANTHA R, TAYLOR KE, BISWAS N and BEWTRA JK (2001) A continuous system for $\mathrm{Fe}^{0}$ reduction of nitrobenzene in synthetic wastewater. Environ. Sci. Technol. 35 3231-3236.

MATHESON LJ and TRATNYEK PG (1994) Reductive dehalogenation of chlorinated methanes by iron metal. Environ. Sci. Technol. 28 2045-2053.

McGUIRE MM, CARLSON DL, VIKESLAND PJ, KOHN T, GRENIER AC, LANGLEY LA, ROBERTS AL and FAIRBROTHER DH (2003) Applications of surface analysis in the environmental sciences: dehalogenation of chlorocarbons with zero-valent iron and iron-containing mineral surfaces. Anal. Chim. Acta 496 301-313.

MIELCZARSKI JA, ATENAS GM and MIELCZARSKI E (2005) Role of iron surface oxidation layers in decomposition of azodye water pollutants in weak acidic solutions. Appl. Catal. B56 289-303.

MORRISON SJ, METZLER DR and DWYER BP (2002) Removal of As, Mn, Mo, Se, U, V and $\mathrm{Zn}$ from groundwater by zero-valent iron in a passive treatment cell: reaction progress modeling. J. Contam. Hydrol. 56 99-116.

MORRISON SJ, MUSHOVIC PS and NIESEN PL (2006) Early breakthrough of molybdenum and uranium in a permeable reactive barrier. Environ. Sci. Technol. 40 2018-2024.

MUEGGE JP and HADLEY PW (2009) An evaluation of permeable reactive barrier projects in California. Remediation 20 41-57.

MUFTIKIAN R, FERNANDO Q and KORTE N (1995) A method for the rapid dechlorination of low molecular weight chlorinated hydrocarbons in water. Water Res. 29 2434-2439.

NOUBACTEP C, MEINRATH G, DIETRICH P and MERKEL B (2003) Mitigating uranium in ground water: prospects and limitations. Environ. Sci. Technol. 37 4304-4308.

NOUBACTEP C (2006) Contaminant reduction at the surface of elemental iron: the end of a myth (in German). Wasser, Luft und Boden 50 (11/12) 11-12 TT11-14.

NOUBACTEP C, SCHÖNER A, DIENEMANN H and SAUTER M (2006) Investigating the release of co-precipitated uranium from iron oxides. J. Radioanal. Nucl. Chem. 267 21-27.

NOUBACTEP C (2007) Processes of contaminant removal in " $\mathrm{Fe}^{0}$ $\mathrm{H}_{2} \mathrm{O}$ " systems revisited. The importance of co-precipitation. Open Environ. J. 1 9-13.

NOUBACTEP C (2008) A critical review on the mechanism of contaminant removal in $\mathrm{Fe}^{0}-\mathrm{H}_{2} \mathrm{O}$ systems. Environ. Technol. 29 909-920

NOUBACTEP C (2009a) On the operating mode of bimetallic systems for environmental remediation. J. Hazard. Mater. 164 394-395.

NOUBACTEP C (2009b) Metallic iron for environmental remediation: Learning from the Becher Process. J. Hazard. Mater. 168 1609-1612.

NOUBACTEP C (2009c) An analysis of the evolution of reactive species in $\mathrm{Fe}^{0} / \mathrm{H}_{2} \mathrm{O}$ systems. J. Hazard. Mater. 168 1626-1631.

NOUBACTEP C (2009d) Characterizing the discoloration of methylene blue in $\mathrm{Fe}^{0} / \mathrm{H}_{2} \mathrm{O}$ systems. J. Hazard. Mater. 166 79-87.

NOUBACTEP C (2010a) The fundamental mechanism of aqueous contaminant removal by metallic iron. Water $S A 36$ 663-670.

NOUBACTEP C (2010b) Elemental metals for environmental remediation: Learning from cementation process. J. Hazard. Mater. 181 $1170-1174$.

NOUBACTEP C (2010c) The suitability of metallic iron for environmental remediation, Environ. Progr. 29 286-291.

NOUBACTEP C (2011) Characterizing the reactivity of metallic iron in $\mathrm{Fe}^{0} / \mathrm{U}^{\mathrm{VI}} / \mathrm{H}_{2} \mathrm{O}$ systems by long-term column experiments. Chem. Eng. J. 171 393-399.

NOUBACTEP C and CARÉ S (2010a) On nanoscale metallic iron for groundwater remediation. J. Hazard. Mater. 182 923-927.

NOUBACTEP C and CARÉ S (2010b) Dimensioning metallic iron beds for efficient contaminant removal. Chem. Eng. J. 163 454-460.

NOUBACTEP C and CARÉ S (2010c) Enhancing sustainability of household water filters by mixing metallic iron with porous materials. Chem. Eng. J. 162 635-642.

NOUBACTEP C and CARÉ S (2011) Designing laboratory metallic iron columns for better result comparability. J. Hazard. Mater. 189(3) 809-813.

NOUBACTEP C and SCHÖNER A (2009) $\mathrm{Fe}^{0}$-based alloys for environmental remediation: Thinking outside the box. J. Hazard. Mater. 165 1210-1214.

NOUBACTEP C, SCHÖNER A and WOAFO P (2009) Metallic iron filters for universal access to safe drinking water. Clean-Soil, Air, Water 37 930-937.

NOUBACTEP C and SCHÖNER A (2010) Metallic iron for environmental remediation: Learning from electrocoagulation. J. Hazard. Mater. 175 1075-1080.

NOUBACTEP C, CARÉ S, TOGUE-KAMGA F, SCHÖNER A and WOAFO P (2010) Extending service life of household water filters by mixing metallic iron with sand. Clean - Soil, Air, Water 38 951-959.

O'HANNESIN SF and GILLHAM RW (1998) Long-term performance of an in situ "iron wall" for remediation of VOCs. Ground Water 36 164-170.

O'LOUGHLIN EJ and BURRIS DR (2004) Reduction of halogenated ethanes by green rust. Environ. Toxicol. Chem. 23 41-48

O'LOUGHLIN EJ, KEMNER KM and BURRIS DR (2003) Effects of $\mathrm{Ag}^{\mathrm{I}}, \mathrm{Au}^{\mathrm{III}}$, and $\mathrm{Cu}^{\mathrm{II}}$ on the reductive dechlorination of carbon tetrachloride by green rust. Environ. Sci. Technol. 37 2905-2912.

ODZIEMKOWSKI M (2009) Spectroscopic studies and reactions of corrosion products at surfaces and electrodes. Spectrosc. Prop. Inorg. Organomet. Compounds $\mathbf{4 0}$ 385-450.

PHILLIPS DH, VAN NOOTEN T, BASTIAENS L, RUSSELL MI, DICKSON K, PLANT S, AHAD JME, NEWTON T, ELLIOT 
T and KALIN RM (2010) Ten year performance evaluation of a field-scale zero-valent iron permeable reactive barrier installed to remediate trichloroethene contaminated groundwater. Environ. Sci. Technol. 44 3861-3869.

POSTMA D and APPELO CAJ (2000): Reduction of Mn-oxides by ferrous iron in a flow system: column experiment and reactive transport modelling. Geochim. Cosmochim. Acta 64 1237-1247.

RAO P, MAK MSH, LIU T, LAI KCK and LO IMC (2009) Effects of humic acid on arsenic(V) removal by zero-valent iron from groundwater with special references to corrosion products analyses. Chemosphere 75 156-162.

REFAIT PH, ABDELMOULA M and GÉNIN J-MR (1998) Mechanisms of formation and structure of green rust one in aqueous corrosion of iron in the presence of chloride ions. Corros. Sci. $\mathbf{4 0}$ 1547-1560.

REYNOLDS GW, HOFF JT and GILLHAM RW (1990) Sampling bias caused by materials used to monitor halocarbons in groundwater. Environ. Sci. Technol. 24 135-142.

RITTER K, ODZIEMKOWSKI MS and GILLHAM RW (2002) An in situ study of the role of surface films on granular iron in the permeable iron wall technology. J. Contam. Hydrol. 55 87-111.

ROWBOTTOM DP (2011) Kuhn vs. Popper on criticism and dogmatism in science: a resolution at the group level. Stud. Hist. Phil. Sci. A42 117-124.

SATOH Y, KIKUCHI K, KINOSHITA S and SASAKI H (2006) Potential capacity of coprecipitation of dissolved organic carbon (DOC) with iron(III) precipitates. Limnol. 7 231-235.

SHI Z, NURMI JT and TRATNYEK PG (2011) Effects of nano zerovalent iron on oxidation-reduction potential. Environ. Sci. Technol. 45 1586-1592.

SCHREIER CG and REINHARD M (1994) Transformation of chlorinated organic compounds by iron and manganese powders in buffered water and in landfill leachate. Chemosphere 29 1743-1753.

SCHERER MM, RICHTER S, VALENTINE RL and ALVAREZ PJJ (2000) Chemistry and microbiology of permeable reactive barriers for in situ groundwater clean up. Rev. Environ. Sci. Technol. 30 363-411.

SCHÜTH C, BILL M, BARTH JAC, SLATER GF and KALIN RM (2003) Carbon isotope fractionation during reductive dechlorination of TCE in batch experiments with iron samples from reactive barriers. J. Contam. Hydrol. 66 25-37.

SCOTT TB, POPESCU IC, CRANE RA and NOUBACTEP C (2011) Nano-scale metallic iron for the treatment of solutions containing multiple inorganic contaminants. J. Hazard. Mater. 186 280-287.

SIMON F-G, BIERMANN V, SEGEBADE C and HEDRICH M (2004) Behaviour of uranium in hydroxyapatite-bearing permeable reactive barriers: investigation using ${ }^{237} \mathrm{U}$ as a radioindicator. $S c i$. Total Environ. 326 249-256.
SIMON FG, BIERMANN V and PEPLINSKI B (2008) Uranium removal from groundwater using hydroxyapatite. Appl. Geochem. 23 2137-2145.

STONE AT (1987) Microbial metabolites and the reductive dissolution of manganese oxides: Oxalate and pyruvate. Geochim. Cosmochim. Acta 51 919-925.

STONE AT and ULRICH H-J (1989) Kinetics and reaction stoichiometry in the reductive dissolution of manganese(IV) dioxide and co(III) oxide by hydroquinone. J. Colloid Interface Sci. 132 509-522.

SU C and PULS RW (2004) Significance of iron(II,III) hydroxycarbonate green rust in arsenic remediation using zerovalent iron in laboratory column tests. Environ. Sci. Technol. 38 5224-5231.

THIRUVENKATACHARI R, VIGNESWARAN S and NAIDU R (2008) Permeable reactive barrier for groundwater remediation. J. Ind. Eng. Chem. 14 145-156.

TIPPING E (1986) Some aspects of the interactions between particulate oxides and aquatic humic substances. Mar. Chem. 18 161-169.

TIPPING E and HIGGINS DC (1982) The effect of adsorbed humic substances on the colloid stability of haematite particles. Colloids Surf. 5 85-92.

TRATNYEK PG and SALTER AJ (2010) Response to comment on "degradation of 1,2,3-trichloropropane (TCP): Hydrolysis, elimination, and reduction by iron and zinc". Environ. Sci. Technol. 44 3198-3199.

VANSTONE N, PRZEPIORA A, VOGAN J, LACRAMPECOULOUME G, POWERS B, PEREZ E, MABURY S and LOLLAR BS (2005) Monitoring trichloroethene remediation at an iron permeable reactive barrier using stable carbon isotopic analysis. J. Contam. Hydrol. 78 313-325.

WANG CB and ZHANG W-X (1997) Synthesizing nanoscale iron particles for rapid and complete dechlorination of TCE and PCBs. Environ. Sci. Technol. 31 2154-2156.

WEBER EJ (1996) Iron-mediated reductive transformations: investigation of reaction mechanism. Environ. Sci. Technol. 30 716-719.

WILDERER PA, BUNGARTZ H-J, LEMMER H, WAGNER M, KELLER J and WUERTZ S (2002) Modern scientific methods and their potential in wastewater science and technology. Water Res. 36 370-393.

WILKIN RT and McNEIL M (2003) Laboratory evaluation of zerovalent iron to treat water impacted by acid mine drainage. Chemosphere $\mathbf{5 3} 715-725$.

YAO K-M, HABIBIAN MT and O'MELIA CR (1971) Water and waste water filtration: concepts and applications. Environ. Sci. Technol. 5 1105-1112.

YUAN S, ZHENG Z, MENG X-Z, CHEN J and WANG L (2010) Surfactant mediated HCB dechlorination in contaminated soils and sediments by micro and nanoscale $\mathrm{Cu} / \mathrm{Fe}$ Particles. Geoderma 159 165-173 
Available on website http://www.wrc.org.za ISSN 0378-4738 (Print) = Water SA Vol. 37 No. 3 July 2011 